\title{
Environmental Evaluation Proposals for Social Housing
}

\author{
Leonardo Flores González, M.Sc. ${ }^{1}$, Edward Santa María Dávila, M.Sc. ${ }^{1}$, Marck Steewar Regalado Espinoza, Eng. ${ }^{1}$, \\ and José Benjamín Lucero Ccencho, Bach. ${ }^{1}$ \\ ${ }^{1}$ National University of Engineering, Lima, Peru, leo_flo_gon_2005@yahoo.com, edsantad@hotmail.com, \\ marck.regalado.e@uni.pe, jluceroc@uni.pe
}

\begin{abstract}
In Peru has been built many households without any planning, contribution or supervision by the local authorities, especially the homes of poor people, shaping slums or rustic zones. How sustainable are social housing in Lima and in dwellings in rural areas? This article describes the Environmental Certification Proposal for Social Housing in Peru, based in needs for evaluation of sustainability of basic infrastructure in cities. Next, construes the parameters for houses in rural areas of the Andean mountains, affected by very cold temperatures in the winter period.
\end{abstract}

Keywords-- Quality, Health, Sustainability, Indoor air quality, Social housing.

\section{INTRODUCTION}

Last years in Peru there has been a migration of the traditional construction systems (mudbrick, "quincha", wood, stone) towards to "noble materials" (masonry systems with clay bricks and cement mortar), due to an alleged better seismic response, but also to other more plausible aspects such as flexibility in the acquisition (availability in building materials stores, flexible storage, accessible unit costs) that allow the development of self-construction (defined as the progressive construction carried out by the owners of single-family housing based on economic availability, and without planning) and even in architectural flexibility (lower surface footprint with respect to adobe masonry, which can translate into greater useful area). On the other side, the social housing has another issues related to energy consumption, transport network accessibility, indoor air quality, quality of life and many other parameters can be translating like Sustainability for Social Housing.

Also, Peru is a country composed of a variable geography, which causes many natural phenomena to occur in different periods throughout its territory. One of these phenomena is Frost, whose main characteristic is the critical decrease in temperature at $0^{\circ} \mathrm{C}$ or less. This phenomenon develops, mainly, in the central Andes, having a major impact in the southern zone and basically occurs due to the decrease of cloudiness in the Andes during the period of April - September. On the other hand, houses in rural areas are structures fabricated with mudbricks or "tapial" as the main building element (approximately $70 \%$ of homes). They are units that have been built by their owners, without technical advice and with minimal intervention during their useful life or operation period.

In this context, the current state of high Andean rural housing does not guarantee to be the space of

Digital Object Identifier (DOI):

http://dx.doi.org/10.18687/LACCEI2020.1.1.572

ISBN: 978-958-52071-4-1 ISSN: 2414-6390 providing protection and comfort to its inhabitants; evidencing, therefore, a qualitative deficiency in this type of housing in terms of infrastructure and the use of new techniques, and thus can avoid the constant exposure to extreme temperatures of its inhabitants.

\section{A. Background}

Reference [1] explain that the world is currently confronting problems such as climate change, environmental pollution and the depletion of natural resources. Reference [2] indicates that for all this the term "Sustainability" was created, defined as the characteristic of satisfying the needs of the present, without compromising future generations. Thus, due to the high incidence of the construction sector in these global problems, different countries have proposed a series of certifications that allow accrediting that a building complies with being "sustainable". An example of these is LEED in the USA and BREEAM in the UK, which consist of a series of indicators, divided into categories, that allow to obtain scores which will finally certify the building.

Reference [3] present LEED (Leadership in Energy and Environmental Design), which is a model of sustainable building certification from the USA, which was created in 2000 by the USGBC (U.S. Green Building Council). It's composed of 7 categories: sustainable sites, water efficiency, energy and atmosphere, materials and resources, indoor environment quality, design innovation and regional priority. In total, it has a maximum of 110 points in all its indicators. Obtaining between 40 and 49 points results in the Approved level, with 50 to 59 points in the Silver level, 60 to 79 points in the Gold level and 80 to 110 points in the Platinum level. LEED has been the most used model in Peru, until 2019 it has obtained 88 certifications, 82 of which are located in its capital Lima, 6 of them get the highest approval scale "Platinum" (U.S. Green Building Council).

Reference [4] present BREEAM (Building Research Establishment Environmental Assessment Methodology), which is the certification from UK, which was created in 1990. It includes a total of 10 categories: Management, Health and Welfare, Energy, Transport, Water, Materials, Waste, Ecological Land Use, Pollution and Innovation. In the case of this certification, a percentage calculation is made with respect to the total points that cover all the indicators, so that if between 30 and $44 \%$ are obtained, the condition of Certified is acquired, with 45 to $54 \%$ the condition of Good, with 55 to $69 \%$ the condition of Very Good, with 70 to $84 \%$ the condition of Excellent and with more than $84 \%$ the condition of Exceptional. 


\section{GREEN UNI PROPOSAL}

This proposal has been developed with academic focus at National University of Engineering (UNI, Peru). It was intended to evaluate some parameters of sustainability of existing buildings destined to social housing. Similar to LEED and BREEAM, GREEN UNI has divided the indicators into 4 categories, will explain the dimension of sustainability that each one covers, as well as the aspects and impacts related to them (See Table I).

TABLE I

GREEN UNI CERTIFICATION MODEL COMPONENTS

\begin{tabular}{|c|c|c|c|}
\hline Indicator & $\begin{array}{l}\text { Sustainability } \\
\text { Dimension }\end{array}$ & Related Aspect & Analyzed Impact \\
\hline \multicolumn{4}{|c|}{ Category 01: Harmony Of The Building With The Exterior } \\
\hline Vulnerability Level & Social & Home safety from natural hazards & Exposure to floods or land movements \\
\hline Building Location & Environmental & Construction in an undeveloped area & $\begin{array}{l}\text { Modification of the landscape, loss of } \\
\text { green areas and agricultural land }\end{array}$ \\
\hline Land Use & Environmental & $\begin{array}{l}\text { Alteration of natural land for the } \\
\text { construction of the building }\end{array}$ & Waterproofing the natural land \\
\hline \multirow{2}{*}{$\begin{array}{l}\text { Proximity to basic } \\
\text { services }\end{array}$} & Environmental & $\begin{array}{c}\text { Type of transport to access basic } \\
\text { services }\end{array}$ & $\begin{array}{l}\text { GHG emissions from the use of vehicles } \\
\text { when having remote services }\end{array}$ \\
\hline & Social & $\begin{array}{l}\text { People's health when using sustainable } \\
\text { means of transport }\end{array}$ & $\begin{array}{c}\text { Do not use transportation alternatives } \\
\text { such as walking or bicycling if the } \\
\text { services are far away }\end{array}$ \\
\hline \multirow{3}{*}{$\begin{array}{l}\text { Access to public } \\
\text { transport }\end{array}$} & Environmental & \multirow{3}{*}{$\begin{array}{l}\text { Proximity of the building to public } \\
\text { transport stations }\end{array}$} & $\begin{array}{c}\text { Increased GHGs from use of private } \\
\text { vehicles }\end{array}$ \\
\hline & Social & & $\begin{array}{c}\text { Problems connecting to the city and its } \\
\text { services }\end{array}$ \\
\hline & Economic & & Higher private transport costs \\
\hline Bicycle parking lots & Environmental & $\begin{array}{l}\text { Promote the use of bicycles by having } \\
\text { safe and sufficient parking lots }\end{array}$ & $\begin{array}{l}\text { Not using this sustainable means of } \\
\text { transport due to lack of parking }\end{array}$ \\
\hline Workplaces & Economic & $\begin{array}{c}\text { Number of jobs generated by the } \\
\text { building in its environment }\end{array}$ & $\begin{array}{l}\text { Few or no jobs generated as a result of the } \\
\text { building }\end{array}$ \\
\hline \multicolumn{4}{|c|}{ Category 02: Building Efficiency } \\
\hline Energy Footprint & Environmental & Energy consumption & \multirow{2}{*}{$\begin{array}{c}\text { Exhaustion of non-renewable resources } \\
\text { and GHG emissions (which generate } \\
\text { Climate Change) }\end{array}$} \\
\hline Clothes Drying & Environmental & $\begin{array}{c}\begin{array}{c}\text { Energy consumption by use of electric } \\
\text { dryers }\end{array} \\
\end{array}$ & \\
\hline Water footprint & Environmental & Water consumption & Water depletion \\
\hline \multicolumn{4}{|c|}{ Category 03: Indoor Comfort } \\
\hline Thermal comfort & Social & Temperature levels inside the building & $\begin{array}{l}\text { Health problems, lack of concentration, } \\
\text { etc. }\end{array}$ \\
\hline $\begin{array}{l}\text { Hygrothermal } \\
\text { comfort }\end{array}$ & Social & Humidity levels inside the building & Breathing problems from mites or mold \\
\hline Lighting comfort & Social & Light levels inside the building & $\begin{array}{c}\text { Eye strain, loss of concentration, stress, } \\
\text { etc. }\end{array}$ \\
\hline Acoustic comfort & Social & Sound levels inside the building & $\begin{array}{l}\text { Loss of concentration, headaches, stress, } \\
\text { etc. }\end{array}$ \\
\hline \multicolumn{4}{|c|}{ Category 04: Indoor Quality } \\
\hline CO2 Concentration & Social & CO2 levels inside the building & $\begin{array}{c}\text { Headaches, nausea, and others caused by } \\
\text { high levels of CO2 }\end{array}$ \\
\hline Air quality & Environmental & $\begin{array}{l}\text { Number of green areas within the } \\
\text { building }\end{array}$ & $\begin{array}{c}\text { Insufficient or no green areas to purify the } \\
\text { environment }\end{array}$ \\
\hline Water quality & Social & $\begin{array}{l}\text { Water parameters related to its } \\
\text { potability }\end{array}$ & Water without drinking conditions \\
\hline
\end{tabular}


A. Category 01: Harmony of the Building with the Exterior

1) Vulnerability Level

Reference [5] indicates that there are areas in Peru exposed to natural hazards, such as "Huaycos" land movements or floods. Fig. 1 is the external geodynamics map generated by the Peruvian Ministry of Environment, and it's proposed to locate the evaluated building in this.

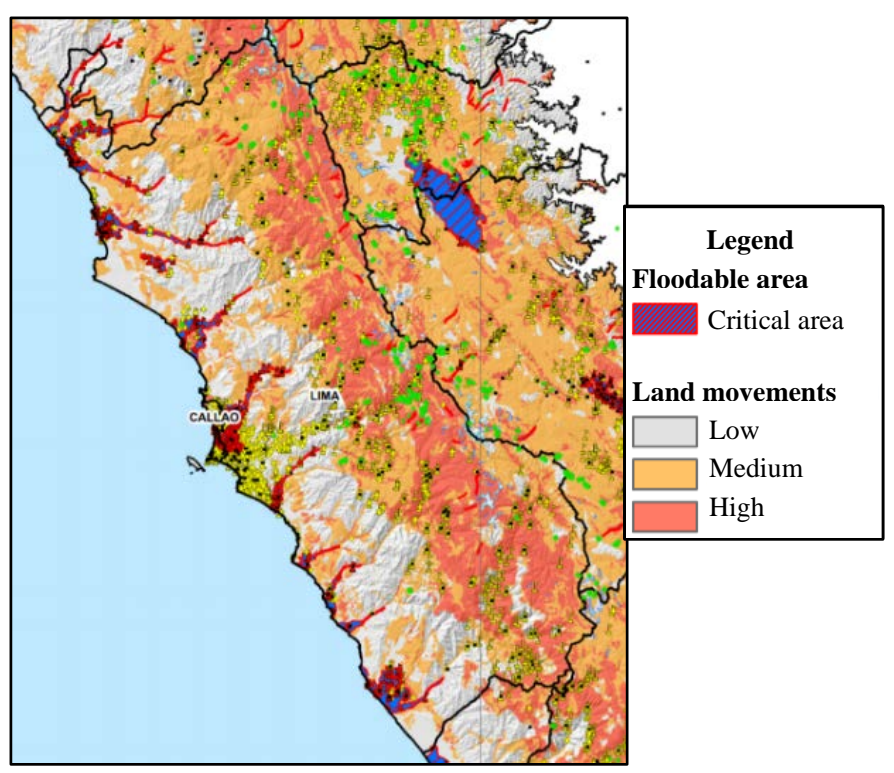

Fig. 1 Map of areas exposed to "Huaycos" and floods [6]

Depending on its location on the map, it is proposed to assign a score. The scores vary from 0 to 2 points, 0 for unsafe conditions against floods and avalanches.

\section{2) Building Location}

It is proposed to identify whether the building is located on land without previous development, such as farming areas, wilderness areas or parks. The scores vary from 0 to 1 point, 0 for housing that have fully footprint in green areas.

\section{3) Land Use}

Reference [7] indicates that in Lima, there is very little population using a large area of land. Therefore, it's proposed to compare the built area with the affected land area (1).

$$
I_{\text {at }}=\frac{\text { Built area }\left(\mathrm{m}^{2}\right)}{\text { Affected land area }\left(\mathrm{m}^{2}\right)}
$$

Depending on the value of (1), a score is assigned, from 0 for the lower performance and 3 for better performance.

4) Proximity to basic services

Reference [8] explain that as an impediment to urban development, the lack of access to basic services is recognized: education, health, recreation, etc. It is proposed to quantify them within a radius of 600 meters and weigh them with respect to the frequency with which they are used (see Table II).
TABLE II

WEIGHT ACCORDING TO BASIC SERVICES

\begin{tabular}{cc}
\hline Weight & Basic service \\
\hline 5 & Warehouses, market or supermarket \\
\hline 4 & University, institute or college \\
\hline 3 & Restaurant or gymnasium \\
\hline 2 & Clinic, hospital, pharmacy or park \\
\hline 1 & Church or temple of prayer \\
\hline
\end{tabular}

Then, the following calculation is made (2).

$$
I_{c s b}=\sum(\text { Weight })(\# \text { Basic Service })
$$

Finally, lower than 50 is correlated to 0 points, ranges from 50 to 200 is correlated to 1 point, ranges 200 to 350 is correlated to 2 points, and higher than 350 is correlated to 3 points.

\section{5) Access to public transport}

It's proposed to recognize the number of public transport stations within a radius of 750 meters, with the center at the main entrance of the building. Then, during 15 minutes in each one, recognize the amount of vehicles of different types (see Table III).

TABLE III

WEIGHT ACCORDING TO TYPE OF PUBLIC TRANSPORT

\begin{tabular}{cc}
\hline Weight & Vehicle type \\
\hline 12 & Lima Subway \\
\hline 8 & Express bus ("Metropolitano”) \\
\hline 5 & Corridor bus \\
\hline 3 & Medium bus \\
\hline 1 & "Combi” \\
\hline
\end{tabular}

Considering all the stations, use (3):

$$
I_{\text {cstp }}=\sum(\text { Weight })(\# \text { vehicle })
$$

Finally, the following points are proposed: 0 points for values below 200, 1 point from 200 to 300, 2 points from 300 to 400,3 points for values greater than 400 .

6) Bicycle parking lots

Reference [9] explains that in the city of Lima, there is a high level of insecurity due to bicycle theft. Thus, it's proposed to identify the number of safe parking spaces that the building has (4):

$$
I_{\text {feb }}=\frac{\# \text { Bicycle parking lots }}{\# \text { residents }} * 100 \%
$$

Finally, 0 points is correlated to $0 \%, 1$ points from $0 \%$ to $10 \%, 2$ points from $10 \%$ to $20 \%, 3$ points for values greater than $20 \%$. 


\section{7) Workplaces}

Reference [10] indicates that one of the components of well-being is to have a job. Because of this, it's proposed to calculate the number of workplaces created within the building (5).

$$
I_{\text {ptg }}=\frac{\# \text { Workplaces }}{\# \text { residents }} * 100 \%
$$

Finally, it's obtained 0 points for values below than $10 \%$, 1 point from $10 \%$ to $15 \%$, 2 points for values greater than $15 \%$.

\section{B. Category 02: Building Efficiency}

1) Energy Footprint

Reference [11] explain that in Peru, about $43 \%$ of electrical energy is produced by burning fossil fuels, including natural gas. Reference [12] indicates that the residential sector is the second largest consumer of electricity in Peru, after the industrial sector. To evaluate the electricity consumption in the building, $50 \mathrm{KWh} /$ month/person is proposed as the ideal consumption. This is multiplied by the number of residents (6):

$$
\text { Ideal consumption }(\text { KWh } / \text { month })=50(\# \text { residents })(6)
$$

This value is compared to the actual consumption of the dwelling in the same units (7):

$$
I_{c e}=\frac{\text { Real }- \text { Ideal }}{\text { Ideal }} * 100 \%
$$

Finally, it is proposed to assign points according to this: 0 points for values higher than $0 \%, 1$ point from -10 to $0 \%, 2$ points from -20 to $-10 \%, 3$ points from -30 to $-20 \%, 4$ points from -40 to $-30 \%$, and 5 points for values below than $-40 \%$.

\section{2) Clothes Drying}

Reference [13] explain that in Lima, the second most energy-consuming household appliance is the clothes dryer. It's proposed to measure the length of cables for natural drying (8).

$$
I_{z s r}(m)=\frac{\text { Length of cable for natural drying }(m)}{\# \text { residents }}
$$

Thus, a score is assigned: 0 points for values below $2 \mathrm{~m}$, and 1 point greater than $2 \mathrm{~m}$.

\section{3) Water footprint}

Reference [14] explain that in Lima, $150 \%$ more than the 100 liters of water per person recommended by the WHO is being consumed. The ideal consumption of 85 liters/person/day is proposed (9).

$$
\text { Ideal }(\text { lt })=85(\# \text { residents })(\# \text { days })
$$

This value is compared to the actual consumption of the housing in the same units (10).

$$
I_{c h}(\%)=\frac{\text { Real }- \text { Ideal }}{\text { Ideal }} * 100 \%
$$

Depending on the result of the equation, a score is assigned. 0 points for values higher than $0 \%, 1$ point from $-15 \%$ to $0 \%, 2$ points from -30 to $-15 \%, 3$ points from -45 to $-30 \%$, and 4 points for values below than $-45 \%$.

\section{Category 03: Indoor Comfort}

1) Thermal comfort

Reference [15] explain that for a proper thermal comfort in Lima (Peru), the temperature during summer should be between 20.7 to $24.8{ }^{\circ} \mathrm{C}$ and during winter between 18.3 to $21.7^{\circ} \mathrm{C}$. A weighted average of compliance is generated in each room (11).

$$
I_{c t}=\frac{\sum \text { Room area that satisfies the standard }\left(\mathrm{m}^{2}\right)}{\sum \text { Room area }\left(\mathrm{m}^{2}\right)} * 100 \%
$$

Depending on the result, the assignment of scores is proposed: 0 points for values below $60 \%, 1$ point from 60 to $80 \%$ and 2 points from 80 to $100 \%$.

\section{2) Hygrothermal comfort}

Reference [15] explain that in Lima (Peru), the comfort humidity level is between 20 and $80 \%$ to prevent the appearance of mites and mold, which are harmful to respiratory health. It's proposed to assign a weight according to the interval in which it is found (see Table IV).

TABLE IV

WEIGHT BY HUMIDITY LEVEL

\begin{tabular}{cc}
\hline Humidity range (\%) & Weight \\
\hline$\langle 20 ; 60] \%$ & 1.5 \\
\hline$\langle 60 ; 70] \%$ & 1.0 \\
\hline$\langle 70 ; 80] \%$ & 0.5 \\
\hline Greater than $80 \%$ or less than $20 \%$ & 0.0 \\
\hline
\end{tabular}

Then, a weighted average is made (12).

$$
I_{c t}=\frac{\sum \text { Weight } * \text { Room area }\left(\mathrm{m}^{2}\right) * 100 \%}{1.5 * \sum \text { Room area }\left(\mathrm{m}^{2}\right)}
$$

Depending on the result, the assignment of scores is proposed: 0 points for values below $60 \%, 1$ point from 60 to $80 \%$ and 2 points from 80 to $100 \%$.

\section{3) Lighting comfort}

Reference [16] explain that light influences alertness, eating habits, mood, etc. The absence of natural light causes drowsiness, inattention, discouragement, depression, stress, fatigue and poor performance. Reference [17] is the Peruvian standard established by the Ministry of Housing, and will be compared with the actual conditions of each room (13).

$$
I_{c v}=\frac{\sum \text { Room area that satisfies the standard }\left(m^{2}\right)}{\sum \text { Room area }\left(m^{2}\right)} * 100 \%
$$


With regard to the calculated value, the assignment of points is proposed: 0 points for values below than $60 \%, 1$ point from 60 to $80 \%$, and 2 points from 80 to $100 \%$.

\section{4) Acoustic comfort}

Reference [18] indicates that according to Peruvian standards, the sound intensity level for residential areas must be a maximum of $60 \mathrm{db}$ during daytime and $50 \mathrm{db}$ at night. The following weighted average is therefore calculated (14).

$$
I_{c a}=\frac{\sum \text { Room area that satisfies the standard }\left(\mathrm{m}^{2}\right)}{\sum \text { Room area }\left(\mathrm{m}^{2}\right)} * 100 \%
$$

With regard to the calculated value, the assignment of points is proposed: 0 points for values below than $60 \%, 1$ point from 60 to $80 \%$, and 2 points from 80 to $100 \%$.

\section{Category 04: Indoor Quality}

\section{1) $\mathrm{CO}_{2}$ Concentration}

Reference [19] indicates that when the concentration of $\mathrm{CO}_{2}$ is high, it accumulates in the blood and causes problems such as headache, lower mental efficiency, and eye irritation, etc. For the evaluation, the following assessment is proposed (see Table V).

TABLE V

WEIGHT BY $\mathrm{CO}_{2}$ CONCENTRATION

\begin{tabular}{cc}
\hline Range $(\mathrm{ppm})$ & Weight \\
\hline$[0 ; 600]$ & 1.5 \\
\hline$\langle 600 ; 800]$ & 1.0 \\
\hline$\langle 800 ; 1,000]$ & 0.5 \\
\hline More than 1,000 & 0.0 \\
\hline
\end{tabular}

Then, the weighted average is calculated (15).

$$
I_{\text {cai }}=\frac{\sum \text { Weight } * \text { Room area }\left(\mathrm{m}^{2}\right) * 100 \%}{1.5 * \sum \text { Room area }\left(\mathrm{m}^{2}\right)} * 100 \%
$$

With regard to the calculated value, the assignment of points is proposed: 0 points for values below than $60 \%, 1$ point from 60 to $80 \%$, 2 points from 80 to $100 \%$.

\section{2) Air quality}

Reference [20] explain that, for an adequate renewal and purification of the air, the WHO indicates that there should be at least $9 \mathrm{~m}^{2}$ of green areas per person (16).

$$
I_{\text {cae }}=\frac{\text { Total green areas }\left(\mathrm{m}^{2}\right)}{\text { Total number of residents }} * 100 \%
$$

On the basis of the standard, a scaled score is proposed: 0 points for values below than $4 ; 1$ point from 4.0 to 6.5 , 2 points from 6.5 to 9.0, and 3 points for values greater than 9.0.

\section{3) Water quality}

Reference [21] is the Peruvian standard for water quality and, according to that, there are permissible ranges for drinking water.

- $\quad$ The $\mathrm{pH}$ value must be between 6.50 and 8.50.

- Conductivity (AC) at $25{ }^{\circ} \mathrm{C}$ must be $1,500 \mu \mathrm{mho} / \mathrm{cm}$ maximum.

- $\quad$ TDS must be 1000 mg/Lt maximum.

It's calculated (17).

$$
I_{\text {cae }}=\frac{\text { Total adequate } \text { water sources }}{\text { Total } \text { water } \text { sources }} * 100 \%
$$

With regard to the calculated value, the assignment of points is proposed: 0 points for values below $100 \%, 1$ point related to $100 \%$.

\section{E. Results}

The GREEN UNI certification model was applied for Exploratory purposes to a sample of 30 housing buildings in Lima, located in multiple districts. The sampling was taken from a student group with the purpose of calibrating the main

\begin{tabular}{|c|c|c|}
\hline Indicator & Average score & Compliance \\
\hline \multicolumn{3}{|c|}{ Category 01: Harmony Of The Building With The Exterior } \\
\hline Vulnerability Level & 1.90 & $95.0 \%$ \\
\hline Building Location & 0.70 & $70.0 \%$ \\
\hline Land Use & 1.27 & $42.2 \%$ \\
\hline Proximity to basic services & 2.15 & $71.6 \%$ \\
\hline Access to public transport & 0.97 & $32.2 \%$ \\
\hline Bicycle parking lots & 0.07 & $2.2 \%$ \\
\hline Workplaces & 0.60 & $30.0 \%$ \\
\hline \multicolumn{3}{|c|}{ Category 02: Building Efficiency } \\
\hline Energy Footprint & 2.40 & $48.0 \%$ \\
\hline Clothes Drying & 0.70 & $70.0 \%$ \\
\hline Water footprint & 0.53 & $13.3 \%$ \\
\hline \multicolumn{3}{|l|}{ Category 03: Indoor Comfort } \\
\hline Thermal comfort & 0.77 & $38.3 \%$ \\
\hline Hygrothermal comfort & 1.37 & $68.3 \%$ \\
\hline Lighting comfort & 1.23 & $61.7 \%$ \\
\hline Acoustic comfort & 1.23 & $61.7 \%$ \\
\hline \multicolumn{3}{|l|}{ Category 04: Indoor Quality } \\
\hline CO2 Concentration & 1.83 & $91.7 \%$ \\
\hline Air quality & 0.27 & $8.9 \%$ \\
\hline Water quality & 1.00 & $100.0 \%$ \\
\hline
\end{tabular}
indicators. The following results were obtained (see Table VI).

TABLE VI

RESULTS OF THE APPLICATION OF CERTIFICATION 
Fig. 2 is a map of the districts of the city of Lima that have been covered with the exploratory sample of 30 buildings.

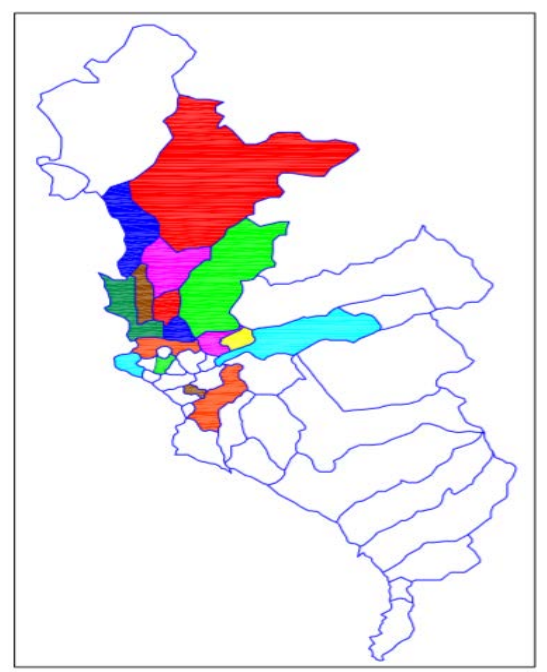

Fig. 2 Districts of Lima covered in exploratory analysis

The districts shown are as follows:

TABLE VII

LIST OF DISTRICTS

\begin{tabular}{|c|c|c|c|}
\hline Ate & Independencia & $\begin{array}{c}\text { Puente } \\
\text { Piedra }\end{array}$ & San Miguel \\
\hline Carabayllo & Jesús María & Rímac & Santa Anita \\
\hline Comas & Lima & $\begin{array}{c}\text { San Juan de } \\
\text { Lurigancho }\end{array}$ & $\begin{array}{c}\text { Santiago de } \\
\text { Surco }\end{array}$ \\
\hline El Agustino & Los Olivos & $\begin{array}{c}\text { San Martín } \\
\text { de Porras }\end{array}$ & Surquillo \\
\hline
\end{tabular}

\section{GREEN ROOF ON RURAL HOUSING}

This proposal has been developed by National University of Engineering (Lima, Peru), with local concerns about cyclical diseases linked to climate in Peruvian rural villages located at high altitudes Andean's mountains.

\section{A. Theoretical Model}

Rural housing is generally composed of 1 or more rectangular modules of $15 \mathrm{~m} \times 30 \mathrm{~m}$, whose ratio of sides varies from 1 to 1.5. Its openings are composed of 1 or 2 doors and windows distributed on the sides in such a way as to increase illumination. The ceilings have a wooden support, mostly covered by calamine (zinc), plastic or asbestos material. With these general considerations, it was decided to take as a model a real house of $4.2 \times 6 \mathrm{~m}$ of base area, with a height of $2.1 \mathrm{~m}$ to $3 \mathrm{~m}$ (shed roof) and calamine cover.

Reference [22] explain that in experiments with scale models for buildings, it's identified that the scales most used for the thermal evaluation are: $1 / 3,1 / 4$ and $1 / 5$.
Then, using scale factor of $1 / 3$, all elements were dimensioned to represent a rural house. Reference [23] indicates that Energy Plus is a complete building energy simulation program that engineers, architects and researchers use to model energy consumption (for heating, cooling, ventilation, lighting and charging of plugs and processes). Such as the use of water in buildings, the thermal performance that would have a rural house with green roof was obtained.

Fig. 3 shows an example of a simplified model of a Housing Module under the interface of the Legacy Open Studio between Sketchup and Energy Plus software.

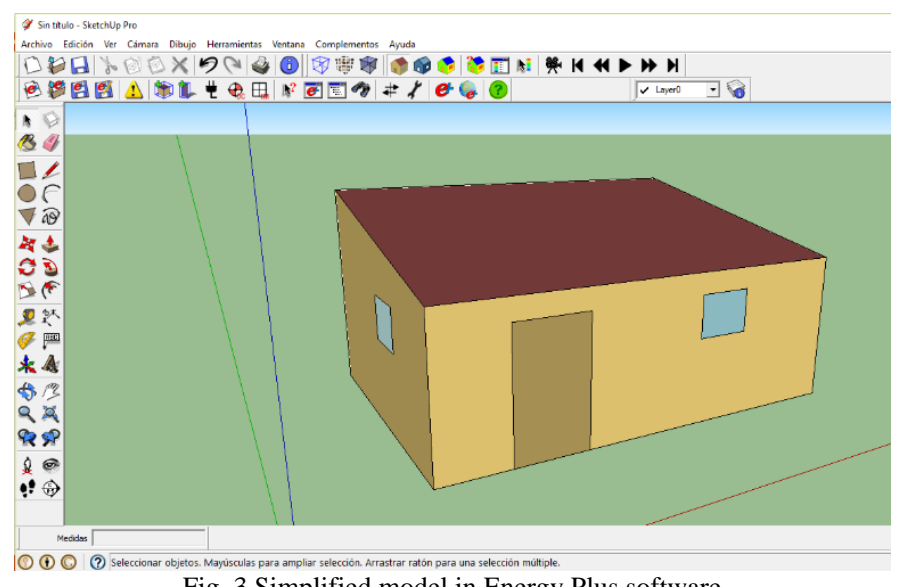

Fig. 3 Simplified model in Energy Plus software

Energy Plus is a free software for thermal and energy simulation for buildings, developed by the Department of Energy (USA). This doesn't have a graphical interface, but it can be connected to SketchUp software through a plugin known as Open Studio.

- SketchUp: Allows the geometric model and the determination of thermal zones.

- Open Studio: It helps to characterize materials, geographic location and meteorological data.

- $\quad$ EnergyPlus: Simulation engine.

EnergyPlus allows to carry out the iterations under the concepts of energy balance, considering the thermal transfer between the indoor air and the building elements (walls, ceiling, floor, openings, and others that are considered in the analysis). This will be, for a volume of control of the air inside a room in each instant:

$$
\begin{array}{r}
\dot{q}_{\text {ALL SURFACES }}+\dot{m}_{\text {INFILTRATION }} \times C_{A I R} \times\left(T_{E X T E N V}-T_{A I R}\right)= \\
\rho_{A I R} \times C e_{A I R} \times \text { Volume Air } \times \frac{\partial T_{A I R}}{\partial t}
\end{array}
$$

When:

- $\dot{\mathrm{q}}_{\text {All SuRfaCEs }}$ : Sum of natural flows of convective heat from each surface in the room.

- $\mathrm{T}_{\text {EXT ENV }}$ : External air temperature in the thermal zone.

- $\mathrm{C}_{\mathrm{AIR}}$ : Specific heat of the air in the room. 
- $\dot{m}_{\text {INFILTRATION }}$ : Mass per time unit that renewed the air in the room.

- Volume Air: Air volume of room.

For this case, after the simulation in EnergyPlus, the following graph was obtained:

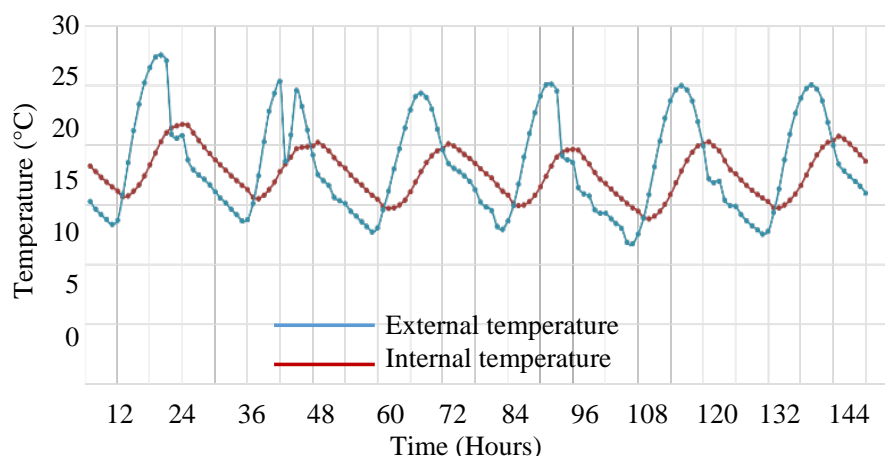

Fig. 4 Theoretical thermal performance of rural housing with green roof

With figure 4, can be identified the next:

- The minimum internal temperature of the model with green roof is $2^{\circ} \mathrm{C}$, higher than the minimum temperature of the model without it.

- The maximum internal temperature of the model with green roof is $5^{\circ} \mathrm{C}$, lower than the maximum temperature of the model without it.

\section{B. Data Logging and Results}

1/3 scale models were constructed according the Peruvian "Adobe" Standard E. 080, following the recommendations of the "Adobe" construction manuals of SENCICO and the Ministry of Housing, Construction and Sanitation of Peru. Fig. 5 is one without green roof and Fig. 6 is the other with green roof.

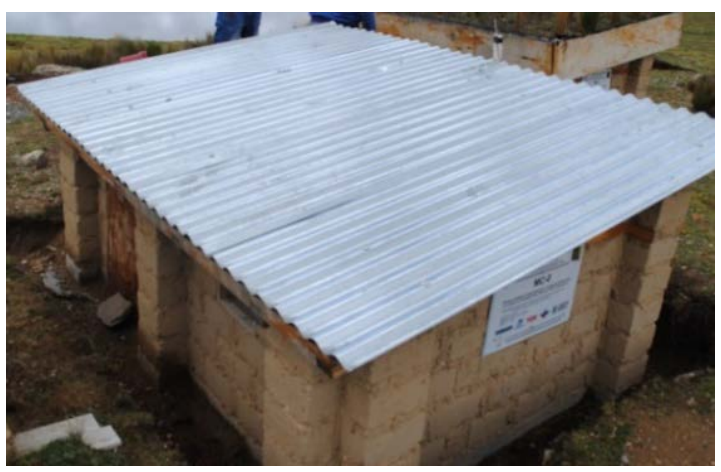

Fig. 5 Scale model without green roof

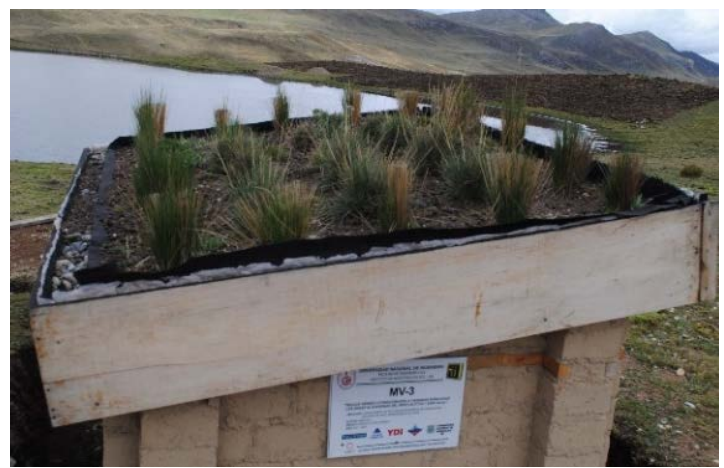

Fig. 6 Scale model with green roof

The data were measured with a "Thermohygrometer", inside both models at the same time, and outside of theme. See Fig. 7 for comparison between these data. It's necessary to emphasize the extreme conditions of the external temperatures with which this measurement has been carried out (less than $\left.0^{\circ} \mathrm{C}\right)$.

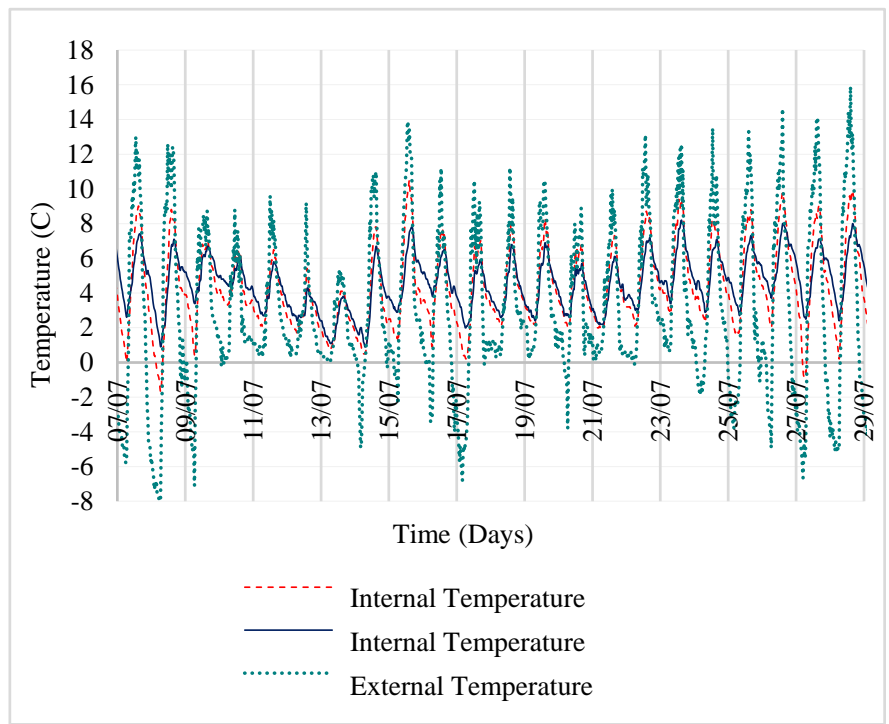

Fig. 7 Data comparison between scale models

Fig. 7 show that green roofs act as a natural insulator, as differences of up to $6^{\circ} \mathrm{C}$ are obtained between the environmental temperature and the temperature inside them. Also, there is a temperature increase of up to $3^{\circ} \mathrm{C}$ in the green roof module housing compared to the module without it, during the coldest hours of the day. Only by improving the conditions of the roof, from a traditional one to a green one, an increase in the internal temperature of the housing module has been achieved.

\section{Social Impact}

Housing, as a fundamental human right, is an important unit of development that should be the space that guarantees a minimum of thermal comfort and provides protection for its inhabitants. In Peru, according to the National Household 
Survey, of the total number of houses in the country, the ratio of urban to rural dwellings is $76.6 \%$ and $23.4 \%$ respectively.

Fig. 8 show that, at the rural level, "Adobe" and "Tapial" are the materials that have the most preference for the houses, reaching about $72.6 \%$ of the total ones.

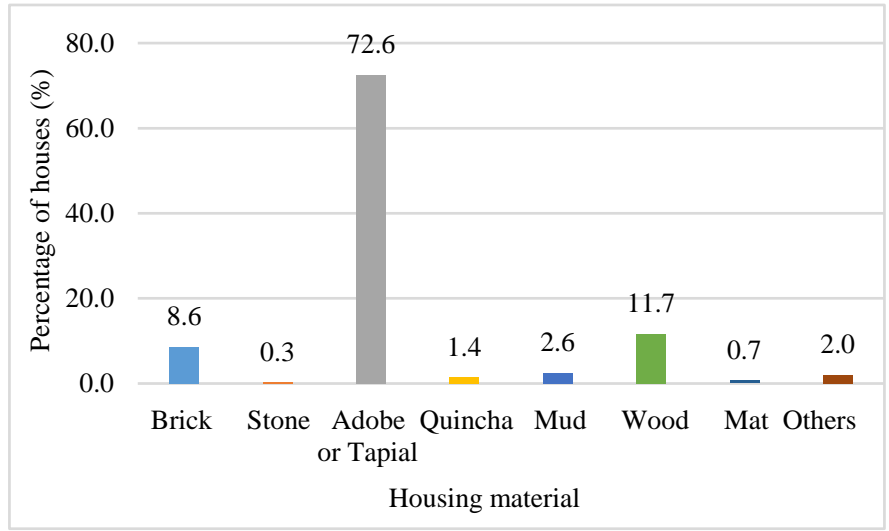

Fig. 8 Housing materials in rural areas

At the same time, Fig. 9 show that the preferred material for roofing in rural areas are the calamines. This is a big problem since the thermal transmittance of this material allow the escape of the heat.

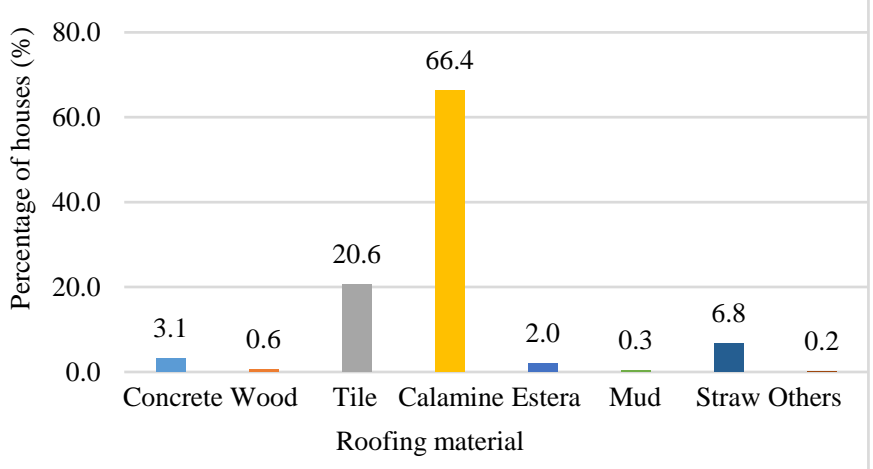

Fig. 9 Roofing materials in rural areas

\section{CONCLUSIONS}

The building evaluation resulted in some indicators with worrying qualifications, i.e. Thermal comfort (38.3\%), Access to public transport (32.2\%) or Workplaces (30.0\%). The poor indicators are Water footprint (13.3\%), Air quality (8.9\%) and Bicycle parking lots (2.2\%).

The measurement of GREEN UNI indicator's is only a sample of some households (students houses in Lima), but reveals concerns about the state of housing in the main city of Peru. However, as indicated, the sample size is only for exploratory purposes, so it's necessary to continue increasing its size.
Green Roof is a good alternative to improve the conditions of $64 \%$ houses in the Peruvian rural area, only conditioning the calamine roof under the green roof proposal.

This research represents an opportunity to strengthen the social housing policy in Peru, since it covers new challenges and commitments taking into account the economic, environmental and cultural parameters that improve the quality of life. In future researches, similar works needs to be replicated in all areas of Peru.

\section{ACKNOWLEDGMENT}

For the students of UNI FIC (National University of Engineering, Civil Engineering Faculty), who collaborated with the measurements in their own dwelling in Lima (Peru).

\section{REFERENCES}

[1] Anand, S. (2013). “Global Environmental Issues”. Open Access Scientific Reports. <https://www.omicsonline.org/scientific-reports/2157-7617-SR632.pdf $>$ (Jan 08, 2020).

[2] United Nations (1987). "Report of the World Commission on Environment and Development: Our Common Future”. Available in: $<$ https://www.are.admin.ch/are/en/home/sustainabledevelopment/international-cooperation/2030agenda/un-_-milestones-insustainable-development/1987--brundtland-report.html> (Jan 08, 2020).

[3] Chance, S. (2012). "Planning for Environmental Sustainability: Learning from LEED and the USGBC”. Planning for Higher Education, 41(1) 194233.

[4] BRE Global Limited (2018). "BREEAM UK New Construction: Nondomestic Buildings (United Kingdom)".

[5] Municipality of Lima (2012). "Manual de autoconstrucción y mejoramiento de vivienda [Self-Construction and Home Improvement Manual]". SENCICO. Peru.

[6] MINAM: Ministry of Environment (2015). "Mapa de susceptibilidad física del Perú [Physical susceptibility map of Peru]”. Peru.

[7] Municipality of Lima (2014). "Memoria de análisis y diagnóstico [Analysis and diagnostic memory]". Peru.

[8] Salazar, José \& Roa, Fernando. "Bogotá: Ciudad Densa y Compacta [Bogota: Dense and Compact City]" [Presentation]. Colombia Chamber of Commerce; November 2008.

[9] Tam, Eduardo W. (2004). "Plan Maestro de Ciclovías para el Área Metropolitana de Lima y Callao [Cycleway Master Plan for the Metropolitan Area of Lima and Callao]”. Peruvian University of Applied Sciences (UPC). Peru.

[10] Alarcón, Rayen A. (2015). "Sostenibilidad Social como resultado de Intervenciones Participativas: El caso del barrio San Francisco de la comuna de El Bosque en el marco del programa Quiero Mi Barrio [Social Sustainability as a result of Participatory Interventions: The case of the San Francisco neighborhood in the district of El Bosque within the framework of the program Quiero Mi Barrio]". University of Chile. Chile.

[11] OSINERGMIN: Supervisory Body for Investment in Energy and Mining (2012). “Operación del Sector Eléctrico: Reporte Estadístico con Información de noviembre 2012 [Electricity Sector Operation: Statistical Report with Information from November 2012]”. Peru.

[12] Carrasco Baca, Sofía A. (2014). "Balance de energía nacional 2014 [National Energy Balance 2014]”. OSINERGMIN. Peru.

[13] RPP News (2018). “Averigua qué electrodoméstico consume más electricidad en tu casa [Find out which household appliance uses the most electricity in your home]". Peru.

$<$ https://rpp.pe/economia/economia/averigua-que-electrodomesticoconsume-mas-electricidad-en-tu-casa-noticia-1083947> (Aug 30, 2018). 
[14] Guy, Howard (2003). "Domestic Water Quantity, Service Level and Health". Loughborough University. United Kingdom.

[15] Wieser Rey, Martín (2006). "LAS TEATINAS DE LIMA. Análisis energético - ambiental y perspectivas de uso contemporáneo [The Theatres of Lima. Energy-environmental analysis and perspectives of contemporary use]”. Universitat Politècnica de Catalunya. Spain.

[16] Herrera V., Anacleto (2007). "Calidad de Iluminación en ambientes de trabajo de la Dirección General de Salud Ambiental [Quality of Lighting in working environments of the General Directorate of Environmental Health]". National University of San Marcos (UNMSM). Peru.

[17] MVCS: Ministry of Housing, Construction and Sanitation (2006). "Norma EM.010 Instalaciones Eléctricas Interiores [Standard EM.010 Interior Electrical Installations]”. Peru.

[18] OEFA: Environmental Assessment and Control Agency (2016). "La contaminación sonora en Lima y Callao [Noise pollution in Lima and Callao]”. Peru.
[19] Rodríguez B., Manuel (2009). “Cambio climático: Lo que está en juego [Climate Change: What's at Stake]". National Environmental Forum. Colombia.

[20] Rendón G., Rosa E. (2010). "Espacios Verdes Públicos y Calidad de Vida. México: Centro Universitario de Arquitectura, Arte y Diseño [Public Green Spaces and Quality of Life Mexico: University Center of Architecture, Art and Design]”. University of Guadalajara. Mexico.

[21] MINSA: Ministry of Health (2011). "Reglamento de la Calidad del Agua para Consumo Humano [Water Quality Regulations for Human Consumption]". General Directorate of Environmental Health. Peru.

[22] Lirola, J. M., Castañeda, E., Lauret, B., \& Khayet, M. (2017). A review on experimental research using scale models for buildings: Application and methodologies. En Energy and Buildings. Elsevier Ltd.

[23] U.S. Department of Energy. (Dec 04, 2019). Energy Plus. Available in: https://energyplus.net/ 